\section{PAULINA OCZKO}

Katolicki Uniwersytet Lubelski Jana Pawła II

https://orcid.org/0000-0003-3292-020X
Copyright and License: Copyright by Instytut Języka Polskiego PAN, Kraków 2021. This article is published under the terms of the Creative Commons Attribution - NoDerivatives 4.0 International (CC BY- ND 4.0) License (https:// creativecommons.org/licenses/by-nd/4.0/legalcode.pl).

\title{
SOCJOLINGWISTYCZNY WYMIAR KOMUNIKACJI MEDYCZNEJ W NAUCZANIU JEZZYKA POLSKIEGO JAKO OBCEGO
}

Słowa kluczowe: polski język medyczny, kompetencja socjolingwistyczna, techniki rozwijania umiejętności socjolingwistycznych, komunikacja medyczna.

\section{STRESZCZENIE}

Artykuł stanowi głos w dyskusji nad zagadnieniem kompetencji socjolingwistycznej w nauczaniu języka polskiego jako obcego do celów specjalistycznych. Tekst ma charakter badawczy i przedstawia jedną z koncepcji dochodzenia do definicji kompetencji socjolingwistycznej. Przeprowadzone pogłębione analizy treści (stanu zastanego) podręczników do nauczania polszczyzny medycznej umieszczono w lingwa- i socjokulturowym nurcie badań lingwistycznych, natomiast kontekst funkcjonalny badanych materiałów lokuje prezentowane rozważania w obrębie specyfiki metodologicznej glottodydaktyki. Głównym celem jest diagnoza świadomości autorów i twórców materiałów do nauczania polskiego języka medycznego pod kątem konieczności rozwijania kompetencji socjolingwistycznej w komunikacji medycznej. W wymiarze poznawczym celem staje się poszerzenie wiedzy w zakresie rozwijania kompetencji socjolingwistycznej w nauczaniu języków specjalistycznych na przykładzie języka medycznego. W pierwszej części artykułu przedstawiono ujęcia teoretyczne kompetencji socjolingwistycznej w nauczaniu języka do celów ogólnych i zawodowych. W drugiej części zaprezentowano koncepcje autorów dotyczące obecności komponentu socjolingwistycznego w materiałach do nauczania polskiego języka medycznego. W części trzeciej skonfrontowano te koncepcje ze stanem rzeczywistym i zawartością podręczników. Analiza materiałów glottodydaktycznych pozwoliła wskazać najczęściej używane techniki służące kształceniu umiejętności socjolingwistycznych, którym poświęcono część czwartą artykułu. Wyniki przeprowadzonych analiz wykazały, że w przeważającej większości podręczników autorzy nie akcentują wyraźnie kompetencji socjolingwistycznej w opisie celów nauczania polskiego języka medycznego, choć w samych materiałach podręcznikowych komponent socjolingwistyczny jest obecny w mniejszym bądź większym stopniu. Do słabych punktów analizowanych materiałów można zaliczyć prezentowanie wyłącznie sytuacji dialogowych lekarz - pacjent, a z pominięciem komunikacji w sytuacjach lekarz - rodzina pacjenta, lekarz-lekarz, lekarz - personel medyczny. To powoduje, że komponent socjolingwistyczny nie jest w pełni przedstawiony osobie uczącej się. Natomiast zaletą podręczników w zakresie aspektu socjolingwistycznego okazuje się zaprezentowanie licznych form powitań, zwrotów adresatywnych oraz zwrotów grzecznościowych. Problem badawczy zasygnalizowany w artykule nie wyczerpał omawianego zagadnienia, daje jednak asumpt do kolejnych badań zorientowanych socjolingwistycznie. 
Nie ulega jednak wątpliwości, że sukces zawodowytzn. pomyślne załatwienie sprawy, transakcji itp. zależy tu również $w$ dużej mierze od opanowania odpowiednich regut socjolingwistycznych.

(Wojnicki 1991, 82)

\section{WSTĘP}

Postępująca globalizacja, wzrost znaczenia Polski na światowym rynku pracy oraz wysoka pozycja polskich uczelni na arenie edukacji międzynarodowej, którą przyniosły minione dwie dekady XXI wieku, wymusiły większe zainteresowanie glottodydaktyków kształceniem specjalistycznym i dały początek m.in. nowym kierunkom badań, które obecnie są definiowane jako glottodydaktyka języków specjalistycznych (Ligara, Szupelak 2012), dydaktyka języków specjalistycznych i - podrzędna wobec niej - dydaktyka (metodyka) języków zawodowych lub branżowych (Gajewska, Sowa 2014) czy glottodydaktyka specjalistyczna (Gębal 2016). Natomiast w materiałach dydaktycznych coraz częściej pojawia się termin nauczanie (języka) komunikacji w miejscu pracy (przedsiębiorstwie) (Gajewska, Sowa 2014)1. To zjawisko Władysław Miodunka podsumował stwierdzeniem: ,sprawa skutecznego nauczania języków specjalistycznych staje się priorytetem dydaktyki języków obcych" (Miodunka 2016, 75). Jednym z języków specjalistycznych, które potrzebują pilnego opracowania na gruncie glottodydaktyki polonistycznej, jest polszczyzna medyczna².

Nauczanie polskiego języka medycznego ma na celu przygotowanie studentów medycyny do efektywnego funkcjonowania zawodowego w środowisku polskojęzycznym. Priorytetem kształcenia w tym zakresie jest doskonalenie kompetencji komunikacyjnej oraz skupienie się na zagadnieniach językowych ściśle wynikających z pracy w środowisku medycznym, w tym - na pogłębianiu znajomości terminologii medycznej i leksyki z zakresu nauk medycznych (Dudzik 2014, 73).

Podręczniki do nauki języka medycznego, jak również sama metodyka nauczania polszczyzny do celów, medycznych nie były dotychczas przedmiotem zainteresowania szerokiego grona badaczy języków specjalistycznych. Niemniej powstało kilka opracowań, które warto przywołać. Na przełomie lat 70. i 80. minionego stulecia pojawiły się

\footnotetext{
${ }^{1}$ Elżbieta Gajewska i Magdalena Sowa proponują również rozróżnienie terminologiczne glottodydaktyki dla potrzeb zawodowych i glottodydaktyki do celów zawodowych (Gajewska i Sowa 2014).

${ }^{2}$ Już od wielu lat ośrodki akademickie stoją przed wyzwaniem tworzenia kursów oraz lektoratów skoncentrowanych na nauczaniu polskiego języka medycznego wśród cudzoziemców. Ponadto lekarz obcokrajowiec, który zamierza podjąć pracę w swoim zawodzie w Polsce, jest zobligowany do potwierdzenia swojej znajomości polszczyzny. Cudzoziemcy są zobowiązani zdać egzamin z języka polskiego, za którego organizację odpowiada Naczelna Izba Lekarska. Zob. Egzaminy z języka polskiego dla lekarzy i lekarzy dentystów. https://nil.org.pl/dla-lekarzy/mlodzi-lekarze/4282-egzaminy-z-jezyka-polskiego (4 lutego 2021).
} 
pierwsze głosy sugerujące pewne założenia teoretyczne i rozwiązania metodologiczne (Danecka-Chwals, Pukas-Palimąka i Chłopicka 1979, 1981; Chłopicka i Pukas-Palimąka 1988). Nowe stulecie przyniosło teksty omawiające sposoby organizowania kursów specjalistycznych (Ławicka-Borońska, Rudnik i Wiśniewska 2011; Swoboda-Rydz 2018). Podejmowano się również weryfikacji treści podręczników pod kątem nauczania terminologii specjalistycznej (Chłopicka-Wielgos i Pukas-Palimąka 1996; Taczyńska 2011; Ławicka-Borońska i Kubicka 2016). Krytycznej analizy doczekały się także techniki rozwijania sprawności językowych (Dębski 1996; Oczko 2020; Oczko 2021 w druku). W dostępnej literaturze brakuje jednak pozycji, które szerzej omawiałyby preparację materiałów do nauczania medycznej odmiany języka polskiego z perspektywy socjolingwistycznej.

\section{PROBLEM, CEL I MATERIAL BADAWCZY}

Głównym celem niniejszego artykułu jest diagnoza świadomości autorów i twórców materiałów do nauczania polskiego języka medycznego pod kątem konieczności rozwijania kompetencji socjolingwistycznej w komunikacji medycznej.

Realizacja tak sformułowanego celu wymaga podjęcia dwóch celów szczegółowych, do których należą:

- $\quad$ po pierwsze - omówienie koncepcji i deklaracji autorów podręczników pod kątem zamieszczania komponentów socjolingwistycznych w materiałach,

- $\quad$ po drugie - weryfikacja tychże założeń ze stanem rzeczywistym materiałów zawartych w książkach.

Tak zaproponowane i przeprowadzone badania będą pierwszym krokiem do wypracowania w przyszłości definicji kompetencji socjolingwistycznej na potrzeby nauczania języka specjalistycznego ${ }^{3}$.

Aspekt socjolingwistyczny komunikacji medycznej-którego dotyczy niniejszy tekst odnosi się do kontekstu społecznego, w którym odbywa się komunikacja, i obejmuje opanowanie społeczno-kulturowego kodu językowego. Dlatego przeprowadzone analizy umieszczono w lingwa- i socjokulturowym nurcie badań lingwistycznych. Z myślą o ustaleniach zawartych w literaturze przedmiotu przez pojęcie lingwakultury rozumiem ,językowy obraz wartości, symboli, sensów i charakterystycznych dla danego obszaru językowego" (Zarzycka 2008, 151), natomiast socjokulture pojmuję jako

[...] kulturę życia społecznego danej wspólnoty, ujawniająca się w tekstach dydaktycznych, wtedy, gdy przekazywana jest wiedza na temat społeczeństwa danego obszaru kulturowego, w szczególności życia codziennego, relacji interpersonalnych i wartości oraz zachowań istotnych dla funkcjonowania w życiu danej społeczności (Zarzycka 2008: 148).

\footnotetext{
${ }^{3}$ Kolejne kroki to opracowanie katalogu zagadnień socjolingwistycznych, socjokulturowych i realioznawczych w komunikacji medycznej, wskazanie stałych i podstawowych komponentów kompetencji socjolingwistycznej (funkcje i akty mowy), ustalenie miejsca oraz roli kompetencji socjolingwistycznej w nauczaniu polszczyzny do celów medycznych.
} 
Kontekst funkcjonalny analizowanych publikacji lokuje prezentowane rozważania w obrębie glottodydaktyki, rozumianej jako praktyki nauczania języków obcych. Materiał źródłowy, który stanowi podstawę do analiz prezentowanych w niniejszym tekście, pochodzi z lat 2007-2020 (łącznie dziewięć pozycji), ponieważ wcześniejsze publikacje mogłyby nie spełniać kryterium zgodności z założeniami Europejskiego systemu opisu kształcenia językowego: uczenie się, nauczanie, ocenianie (dalej ESOKJ), który w formie dokumentu funkcjonuje od 2003 roku . Oprócz kryterium czasowego, uzasadnionego powyżej, w procesie selekcji i doboru materiału glottodydaktycznego istotne stało się również kryterium nomenklatury materiałów dydaktycznych, a ściślej: użycia ich do nauczania komunikacji medycznej ${ }^{5}$.

Niniejszy artykuł wpisuje się w badania nad językiem medycznym, który rozumiem jako konglomerat zjawisk leksykalnych z zakresu medycyny, czyli nauki o chorobach ludzi oraz o sposobach ich leczenia, terminologii specjalistycznej (w tym zapożyczeń z łaciny i greki), a także zawodowej (żargon lekarski) (zob. Müldner-Nieckowski 2014; Magajewska 2016; Chojnacka-Kuraś 2017; Badziński 2019).

Na potrzeby tego tekstu posługuję się terminem komunikacja medyczna za Janem Doroszewskim, według którego to pojęcie ma dwa znaczenia: szerokie i wąskie. W szerszym ujęciu komunikację medyczną należy rozumieć jako ,porozumienie między różnymi - pojedynczymi lub zbiorowymi - podmiotami, które dotyczą spraw związanych z medycyną" (Doroszewski 2007, 43). W tym przypadku mowa o różnorodnych gatunkach tekstów i typach sytuacji komunikacyjnych, która odbywa się między: lekarzem specjalistą a innym lekarzem specjalistą (czasami relacje między lekarzami są zhierarchizowane), lekarzem a członkami zespołu (personelu) medycznego, lekarzem specjalistą (dydaktykiem) a studentem medycyny (lub stażystą), a także lekarzem specjalistą a pacjentem. Ponadto - co wydaje się istotne, a zostało pominięte przez Doroszewskiego - oprócz kontaktu między lekarzem a pacjentem, odbywa się również komunikacja na linii lekarz - rodzina (opiekun) pacjenta (Bartosik 2020, 25). Natomiast „zachodzące w ramach stosunku opieki medycznej, tj. postępowania leczniczego lub zapobiegawczego" porozumiewanie się lekarza, pielęgniarki lub innego przedstawiciela służby zdrowia z pacjentem to wąskie znaczenie komunikacji medycznej (Doroszewski 2007, 43).

Przyjęcie rozumienia komunikacji medycznej w szerszym ujęciu prowadzi do następujących pytań:

1) Jakiej odmiany / jakich odmian języka używa się w środowisku medycznym (przyszłym miejscu pracy osoby uczącej się)?

\footnotetext{
${ }^{4}$ ESOKJ jest istotnym punktem odniesienia w definiowaniu celów nauczania języków obcych. Ten dokument to nie tylko opis wszystkich poziomów, ale przede wszystkim propozycja nowego podejścia w dydaktyce języków obcych (podejścia zadaniowego) - metody, która jest zalecana jest do nauczania języków specjalistycznych.

${ }^{5}$ Wykaz materiałów źródłowych znajduje się na końcu artykułu.
} 
2) W jakiej odmianie / w jakich odmianach osoba ucząca się będzie musiała rozumieć wypowiedzi i czy w tej samej / w tych samych będzie formułować wypowiedzi? Jeśli nie, to w jakiej / w jakich?

3) Jaką wiedzę musi opanować osoba ucząca się, aby został zachowany społeczny wymiar komunikacji?

Tabela 1

Role komunikacyjne a zróżnicowanie stylowe języka opracowanie własne ${ }^{6}$

\begin{tabular}{|l|l|l|}
\hline & Role komunikacyjne & Zróżnicowanie stylowe języka \\
\hline 1 & lekarz specjalista $\leftrightarrow$ lekarz specjalista & $\begin{array}{l}\text { medyczny język naukowy/specjalistyczny, } \\
\text { frazeologia lekarska ścisła, żargon } \\
\text { lekarski }\end{array}$ \\
\hline 2 & lekarz specjalista $\leftrightarrow$ członkowie zespołu medycznego \\
\hline 3 & lekarz specjalista (dydaktyk) $\leftrightarrow$ student medycyny & $\begin{array}{l}\text { medyczny język naukowy/specjalistyczny, } \\
\text { język ogólny }\end{array}$ \\
\hline 4 & lekarz specjalista $\leftrightarrow$ pacjent & język ogólny, styl potoczny, \\
\hline 5 & lekarzyk medyczny dla niespecjalistów \\
\hline
\end{tabular}

Powyższe zestawienie pokazuje, że w środowisku medycznym występuje dosyć wyraźne zróżnicowanie (stylowe) języka. Ta konkluzja jest odpowiedzią zarówno na pierwsze, drugie, jak i na trzecie pytanie zadane na początku. W komunikacji z pacjentem lekarz otrzymuje komunikat w języku ogólnym z elementami stylu potocznego czy gwarowymi. Taki też komunikat lekarz jest zobowiązany zrozumieć. Natomiast wypowiedź/reakcja lekarza będzie przykładem języka specjalistycznego, medycznego dostosowanego do niespecjalisty.

Z kolei odpowiedź udzielona na czwarte pytanie pomoże stworzyć katalog zagadnień socjolingwistycznych, socjokulturowych i realioznawczych w komunikacji medycznej, umożliwi wskazanie komponentów kompetencji socjolingwistycznej (funkcje mowy i akty mowy), jej głównych wyznaczników (czy np. pokrywają się z tymi, które proponują autorzy dokumentu ESOKJ (2003, 106-108). Jest to zadanie niezbędne, jednak wymagające głębszych analiz oraz szerszych badań, które wykraczają poza ramy tego artykułu.

Komunikacja medyczna (lekarz - pacjent) jest szeroko badana i komentowana zarówno w literaturze polskiej, jak i zagranicznej. Jednymi z najważniejszych prac na płaszczyźnie lingwistycznej są publikacje Komisji Języka Polskiego Rady Języka Polskiego PAN (Komunikacja 2006, Komunikacja 2007, Komunikacja 2014). We współczesnych badaniach zwraca się szczególną uwagę na trudne momenty w relacji lekarz - pacjent i podkreśla się, że lekarze nie są uczeni, jak rozmawiać z chorymi i ich rodzinami, jak - przede wszystkim - przekazać niepomyślne wiadomości, jak motywować

\footnotetext{
${ }^{6}$ Nie należy zapominać, że istnieje jeszcze język oświaty zdrowotnej, który odpowiada stylowi popularnonaukowemu (Müldner-Nieckowski 2014, 408).
} 
pacjentów do leczenia ${ }^{7}$ (zob. Sobczak 2014; Jarosz 2013; Sobczak i Leoniuk 2021). Co ciekawe, autorzy Materiałów do nauczania języka polskiego w szkole medycznej dla obcokrajowców, jednego z analizowanych tutaj podręczników, jako jedyni zwrócili uwagę na ten problem:

\section{PAMIĘTAJ: Wielka jest sila lekarskiego słowa!}

Współcześnie dużo dyskutuje się o psychologii relacji lekarza z pacjentem, zwłaszcza w dziedzinach tak trudnych jak onkologia. Psychoonkologia zajmuje się - między innymi - psychologicznymi aspektami przekazywania złych informacji o rozpoznaniu choroby i rokowania. Dominuje dziś pogląd, że problem[em], przed którym stoi lekarz, nie jest to, czy mówić prawdę, ale jak tę niełatwą prawdę przekazywać pacjentowi. Oto trzy zasady, którymi powinien kierować się lekarz:

1. pacjent ma prawo znać cała prawdę o stanie swojego zdrowia, dlatego nie wolno go oszukiwać i dawać mu fałszywych nadziei;

2. prawda pełni funkcje terapeutyczną, dlatego trzeba wyjawić ją stopniowo i w zależności od indywidualnej wrażliwości chorego;

3. należy bezwzględnie unikać brutalnej i bezmyślnej otwartości w rozmowie z chorymi (dlatego można i trzeba używać eufemizmów) (Janeczko i in. 2014, 150).

Maria Konopka trafnie podsumowuje opisane zjawisko: „Koncentracja na istocie rzeczy, na przypadku medycznym, na leczeniu, na boczny tor odsuwa kwestię relacji z podmiotem tychże zabiegów" (Konopka 2016, 69). Podobne zagadnienia badawcze dotyczące komunikacji medycznej zagraniczni językoznawcy podejmują już od kilku dekad (Marshal 1986; Menz 2010; Zhura i Rudova 2019).

\section{KOMPETENCJA SOCJOLINGWISTYCZNA - PRZEGLĄD UJĘĆ TEORETYCZNYCH}

W Małym słowniku terminów z zakresu socjolingwistyki i pragmatyki językowej interesująca mnie kompetencja socjolingwistyczna jest definiowana jako ,idealna znajomość wszystkich reguł używania języka w zależności od sytuacji i roli społecznej” (Skudrzykowa i Urban 2000, 86). Na wiedzę i umiejętności pozwalające respektować społeczny wymiar komunikacji w danym języku zwrócono również uwagę w (glotto)dydaktyce języków ogólnych. W ESOKJ wskazano, że ta kompetencja obejmuje:

1) wyznaczniki relacji społecznych (np. użycie i wybór form powitania, form adresatywnych, wykrzykników, przekleństw, sposobów konwencjonalnego zabierania głosu w rozmowie lub dyskusji);

2) konwencje grzecznościowe (tu grzeczność „pozytywna”, np. wykazywanie zainteresowania dobrym samopoczuciem danej osoby, i ,negatywna”, unikanie zachowań zastraszających, właściwe użycie słów „proszę” i „dziękuję” oraz

\footnotetext{
${ }^{7}$ Por. raport OECD (Organisation for Economic Co-operation and Development) Health at a Glance 2015. https://www.health.gov.il/publicationsfiles/healthataglance2015.pdf (19 marca 2021).
} 
niegrzeczność polegająca na celowym naruszeniu konwencji grzecznościowej poprzez wyrażenie propagandy, niechęci czy udzielenie reprymendy);

3) nośniki „mądrości ludowej” (użycie wyrażeń idiomatycznych, popularnych cytatów oraz przysłów dotyczących wierzeń, postaw i poglądów, wartości);

4) rejestr wypowiedzi (ze względu na złożoność samej definicji rejestru w tym miejscu wskazuje się jedynie na zróżnicowanie stopnia formalności wypowiedzi, czyli sztywne, formalne, neutralne, nieformalne, poufałe i intymne);

5) dialekty i odmiany regionalne (umiejętność rozpoznawania językowych wyznaczników lingwistycznych dla różnych dialektów i typów wymowy, charakterystycznych dla danej klasy społecznej, regionu, narodowości, przynależności do grupy etnicznej lub zawodowej, a grono wskaźników tworzą: leksyka, gramatyka, fonologia, rytm, głośność, mowa ciała) (ESOKJ 2003, 106-108).

Chociaż przydatność dokumentu Rady Europy dla nauczycieli przygotowujących do posługiwania się językiem obcym w kontekście zawodowym nie jest tak oczywista, a ESOKJ niewiele uwagi poświęca specjalistycznemu kształceniu językowemu ${ }^{8}$, nie zmienia to faktu, że obecnie jest to najważniejszy dokument normujący proces nauczania języków obcych i okazuje się istotnym punktem odniesienia we współczesnym kształceniu glottodydaktycznym (Gajewska i Sowa 2014, 125-126) ${ }^{9}$.

Kwerenda literatury przedmiotu prowadzi do wniosku, że zagadnienie kompetencji socjolingwistycznej w nauczaniu języków specjalistycznych jest mało zbadane, a materiały, które dotyczą socjolingwistyki w glottodydaktyce do celów zawodowych, wpisują się w perspektywę badań lingwistycznych, etnolingwistycznych i nie kierują swoich obserwacji na grunt dydaktyki.

Najwięcej badań prowadzono nad kompetencją kulturową w komunikacji zawodowej (zob. Smith i Trompenaars 1996; Hofstede 1997), przez co kompetencję socjolingwistyczna pozostawiono nieco na uboczu.

Jedną z ważniejszych prac podejmujących zagadnienie kompetencji socjolingwistycznej jest artykuł Margaret Simmons pt. „A Sociolinguistic Analysis of Doctor-Patient Communication". Głównym celem badaczki było znalezienie odpowiedzi na pytanie, dlaczego sposoby wypowiadania się lekarzy i pacjentów nie są bardziej podobne do siebie. W swoich badaniach Simmons (1998) wykazała, że czynniki, które ograniczają zdolność pacjentów do swobodnego ,wyrażania siebie”, to: nieznajomość słownictwa medycznego oraz technicznych wzorców gramatycznych.

\footnotetext{
${ }^{8}$ Zagadnienie nauczania języków specjalistycznych (w ESOKJ funkcjonuje również określenie język zawodowy) przewija się przez cały dokument Rady Europy w różnym kontekście. Według autorów strefa zawodowa odnosi się do wszelkich sytuacji, „w których dana osoba podejmuje działania związane ze swoim zawodem i/lub wykonaną pracą” (ESOKJ 2003, 52), a umiejętności zawodowe to „zdolność do działań specjalistycznych (umysłowych i fizycznych) koniecznych do wypełnienia obowiązków związanych z wykonaniem pracy" (ESOKJ 2003, 96).

${ }^{9}$ Przede wszystkim koncepcja uniwersalnych poziomów kompetencji (stanowiąca sedno ESOKJ) oraz gradacja treści i podział na sześć poziomów biegłości językowej zostały zakwestionowane przez glottodydaktykę specjalistyczną (Sowa i Gajewska 2014, 126).
} 
$\mathrm{Na}$ gruncie polskim już na początku lat 90. ubiegłego stulecia, kiedy zaczęto bardziej interesować i zajmować się nauczaniem języków obcych do celów zawodowych, Stanisław Wojnicki podkreślał, że:

\footnotetext{
Reguły socjolingwistyczne natomiast różnią się bardzo w zależności od kraju; rola ich wydatnie wzrasta w komunikacji bezpośredniej, „twarzą w twarz” bądź listowej, i nie sposób opracować dziś poważnego kursu językowego przygotowującego do takiej komunikacji bez ich uwzględnienia. Jest to zagadnienie dużej wagi również w nauczaniu języków obcych do celów zawodowych. W wielu krajach istnieją bardzo sztywne reguły formułowania korespondencji służbowej, handlowej itp., i naruszenie tych reguł może mieć istotny wpływ na realizację celów merytorycznych (Wojnicki 1991, 68).
}

Wzorce socjolingwistyczne są elementem koniecznym do właściwego przebiegu procesu komunikacyjnego w obcym języku. Znajomość i stosowanie reguł funkcjonowania języka w danym społeczeństwie wspomagają kształtowanie umiejętności użycia wyrazów w coraz to nowych połączeniach (Wojnicki 1991, 74).

Dopełnieniem reguł socjolingwistycznych jest wiedza socjokulturowa - Konrad Fuhrmann stwierdza, że

[...] znajomość innych kultur to kolejny problem: język to coś więcej niż słowa i gramatyka. Aby odnieść sukces w biznesie [oraz innych sferach zawodowych - przyp. P.O.], niezbędna jest znajomość kultury, która wyraża się w danym języku. Pracownicy nie tylko powinni znać języki, lecz również powinni poznać, zrozumieć i szanować inne kultury. Takie podejście ma ogromny wpływ na przyszłą współpracę i proces negocjacji. Należy zawsze pamiętać o znaczeniu, jakie ma poznanie kultury. Nauczając języka[,] musimy również uczyć o kulturze danego kraju (Fuhrmann 2012, 182).

\section{KONCEPCJE KSZTALCENIA KOMPETENCJI SOCJOLINGWISTYCZNEJ W MATERIALACH DO NAUCZANIA POLSKIEGO JĘZYKA MEDYCZNEGO}

W tej części dokładniej omówiono autorskie koncepcje kształcenia kompetencji socjolingwistycznej, które zawarto we wstępach do materiałów przeznaczonych do nauczania polskiego języka medycznego. Wnioski płynące z analiz będą stanowiły podstawę do dalszych badań i rozważań.

W następujących podręcznikach: Język polski dla cudzoziemców: dialogi i ćwiczenia dla studentów stomatologii (2013), Materiały do nauczania języka polskiego w szkole medycznej dla obcokrajowców (2013), Język polski dla stomatologów (2016), Proszę oddychać. Materiaty do nauczania medycznego języka polskiego, cz. I (2019) i cz. III (2020), brak nie tylko autorskiego wstępu, lecz także - czasami - spisu treści. Powoduje to, że realizowane w nich koncepcje kształcenia językowego oraz założenia metodyczne muszą pozostać w sferze domysłów. Autor podręcznika Proszę mi powiedzieć, co się stało? (2007) zaznaczył:

Celem książki jest wprowadzenie terminologii medycznej i wykorzystanie jej w rozmowach z pacjentami w czasie praktyk lekarskich. [...] Praca z podręcznikiem pozwala studentom usystematyzować i utrwalić terminologię medyczną i występować w roli lekarza (Turek 2007, 5). 
Z kolei w książce pt. Witaj w Polsce! (2018) autorka również ograniczyła się do ogólnikowej informacji:

Zadania postawione przed studentami w każdej jednostce mają na celu ćwiczenie i utrwalanie nowo poznanego słownictwa medycznego, a także rozwijanie umiejętności efektywnego porozumiewania się z pacjentem i personelem (Bilicka 2018, 10).

W podobnej konwencji utrzymano informacje autorskie w najnowszym podręczniku U lekarza [...] (2019), autorzy napisali: „Opracowanie kładzie szczególny nacisk na kształcenie sprawności rozumienia ze słuchu, poświęca jednak także sporo uwagi słownictwu, rozumieniu tekstu pisanego i komunikacji”. W przywołanych powyżej pozycjach aspekt socjolingwistyczny nie wybrzmiewa explicite.

Dopiero twórczynie podręcznika Co Panu dolega? (2015) pierwsze - i do tej pory jedyne - wyraźnie zwróciły uwagę na konieczność rozwijania kompetencji socjolingwistycznej w nauczaniu języka medycznego:

Autorki zakładają, że uczący się posiadają ogólną wiedzę medyczną, zarówno w swoim języku, jak i w języku polskim, i dlatego większy nacisk kładą na rozwój kompetencji socjolingwistycznej (wyrażanie się w sposób odpowiedni do sytuacji) oraz kompetencji pragmatycznej (użycie języka w interakcjach).

Sytuacja, w której student przyjmuje rolę lekarza, ma istotny wpływ na zróżnicowanie stylowe języka.

W rozmowie z pacjentem czy rodziną pacjenta musi używać języka potocznego, zrozumiałego dla rozmówcy.

Natomiast w kontakcie $\mathrm{z}$ innym lekarzem będzie używał mówionego lub pisanego języka fachowego. W związku z tym istotne są tu intencje użycia języka w konkretnych sytuacjach, czyli tak zwane funkcje językowe.

\section{I następnie:}

Na początku każdej jednostki (podzadanie 1) przedstawia się słownictwo i zwroty podstawowe dla danej dziedziny oraz ćwiczenia mające na celu ich przyswojenie. Słownictwo nacechowane stylistycznie bądź niepoprawne, ale często używane potocznie przez pacjentów lub personel medyczny[,] zostało oznaczone symbolem *, i to zarówno w części słownikowej, jak i [w] tekstach, dialogach, i ćwiczeniach (Chłopicka-Wielgos i in. 2015, 2-3).

Autorki wspomnianej pozycji zajmują się od długiego czasu nauczaniem języka medycznego: w latach 80. i 90. ubiegłego wieku opracowały dwa podręczniki ${ }^{10}$. Wieloletnie doświadczenie twórczyń w nauczaniu polskiego języka medycyny i uwzględnienie przez nie zmieniających się tendencji w nauczaniu języków obcych zaowocowały książką, która jest - jak pisze Zarzycka (2015) w recenzji wydawniczej - ,[...] wzorcowym przykładem współpracy między glottodydaktykami a specjalistą z dziedziny, którą opisuje język podręcznika".

\footnotetext{
${ }^{10}$ Mowa tu o książkach O człowieku po polsku (3 wydania: 1981, 1986, 1989) oraz Co panu dolega? Komunikacyjny podręcznik języka medycznego dla obcokrajowców (1991).
} 
W odautorskim komentarzu do podręcznika wyraźnie wskazują na konieczność rozwijania nie tylko kompetencji socjolingwistycznej, lecz także jej komponentów wynikających z funkcji językowych. Zdaniem autorek nie tyle konieczność, ile potrzeba rozwijania kompetencji socjolingwistycznej wynika z samej specyfiki zawodu lekarza, który na co dzień styka się z różnymi rejestrami języka (styl potoczny, żargon lekarski, język specjalistyczny w mowie i piśmie) i musi podejmować liczne, ale różne czynności językowe, takie jak wydawanie poleceń, ponaglanie, udzielanie porad, zalecenia, wyrażanie nakazów, zakazów, przedstawienie stanu pacjenta, referowanie wyników badań i przebiegu terapii pacjenta oraz przygotowanie pisemnej charakterystyki badanego.

Z przytoczonych tu fragmentów autorskich koncepcji nauczania języka medycznego jasno wynika, że rozwijanie kompetencji socjolingwistycznej - oprócz książki Co Panu dolega? (2015) - jest poza polem zainteresowania twórców materiałów do kształcenia tej odmiany polszczyzny. Choć koncepcje rozwijania komponentu socjolingwistycznego nie wybrzmiały wprost, należy skonfrontować to ze stanem rzeczywistym oraz z treścią podręczników. Ponieważ w dominującej większości można zauważyć niemal identyczne podejście do komunikacji medycznej, a tylko w jednym opracowaniu Co Panu dolega? (2015) zwrócono wprost uwagę na konieczność rozwijania kompetencji socjolingwistycznej, ten ostatni przykład zostanie opatrzony oddzielnym komentarzem.

\section{ANALIZA ZAWARTOŚCI TREŚCI PODRĘCZNIKÓW W PERSPEKTYWIE SOCJOLINGWISTYCZNEJ}

Kluczem do przeprowadzenia analiz były - zaprezentowane przez ESOKJ - składniki kompetencji socjolingwistycznej, które przytoczyłam w punkcie pierwszym artykułu. Język w omawianych podręcznikach charakteryzuje się dużym stopniem „sterylności”, co z kolei przekłada się na nienaturalny wydźwięk sytuacji komunikacyjnych w nich przedstawionych. To prawda, że dydaktyczny cel książek poddanych analizom wymusza działania, które prowadzą do swego rodzaju idealizacji dyskursu medycznego. Metodyka nauczania języka wręcz zaleca preparowanie i przygotowanie tekstów na niższych poziomach nauki. Materiały w ten sposób przygotowane są pozbawione kontekstu socjolingwistycznego. Udoskonalenie materiałów dydaktycznych poprzez zbliżenie ich do faktycznych praktyk językowych i zwiększenie ich autentyczności przełoży się na pożądany efekt dydaktyczny i lingwistyczny.

Rażący jest wyważony styl rozmówców: pacjenci występujący w dialogach posługują się w wyłącznie językiem ogólnym, miejscami - stylem nazbyt akademickim. Elementy stylu potocznego, pojawiające się sporadycznie, nie zostały w żaden sposób zaznaczone przez autorów jako te, które odbiegają od normy języka ogólnego. Dla zobrazowania zjawiska przytoczę inwentarz leksyki potocznej wyekscerpowanej z podręcznika U lekarza (2019): strasznie, sikać, siki, kupa, załatwić się, okropny, tak sobie, fatalny, maluch, mały (w znaczeniu „dziecko”), ciśnienie książkowe, pacjent pod 
czwórka, trzydniówka, dwudniówka, zatyka mnie, stuch mi się psuje, dostać raka skóry, co ci na to dat?, tokieć tenisisty ${ }^{11}$.

Materiały do nauczania języka medycznego prezentują mało prawdopodobne sytuacje komunikacyjne, w trakcie których zarówno pacjent, jak i lekarz rozumieją komunikat bez większych problemów (lekarz cudzoziemiec nie zawsze wszystko zrozumie, mimo wysokiego poziomu znajomości języka). W tworzeniu materiałów należałoby zwrócić większą uwagę na to, aby uzyskać równowagę między wiarygodnością przedstawionej sytuacji a jej funkcjonowaniem jako materiału dydaktycznego.

Brak również przestrzeni na to, aby lekarz mógł utożsamić się z pacjentem i ,językowo" wcielić się w jego pozycję: uprościć wypowiedzi i odejść od terminologii ściśle medycznej i zbyt zawiłych konstrukcji gramatycznych na rzecz leksyki bardziej zrozumiałej dla rozmówcy. To z kolei utwierdza uczących się w błędnym przekonaniu, że pacjent zawsze zdoła zrozumieć wypowiedź lekarza.

Niestety, w materiałach glottodydaktycznych przedstawiano sytuacje komunikacyjne, które obecnie są przedmiotem badań i dyskusji językoznawców zajmujących się komunikacją medyczną. Stale zgłasza się potrzebę odejścia od takiego „wzorca” komunikacji lekarz - pacjent. Na uczelniach medycznych wprowadza się obowiązkowe kursy, na których studenci medycyny uczą się, jak prawidłowo i efektywnie komunikować się $\mathrm{z}$ chorym (Sobczak 2014).

Za słaby punkt analizowanych materiałów uznać należy także prezentowanie wyłącznie sytuacji dialogowych lekarz - pacjent (z drobnymi odstępstwami). To powoduje, że komponent socjolingwistyczny nie zostaje w pełni zaprezentowany osobie uczącej się. Daje to również dość wypaczony obraz komunikacji medycznej, ograniczonej zaledwie do kontaktów z osobą chorą.

Natomiast do mocnych stron podręczników w zakresie aspektu socjolingwistycznego należy przede wszystkim uwypuklenie w dialogach form powitania, zwrotów adresatywnych, zwrotów grzecznościowych, rozróżnienie sposobów formułowania pytań i próśb do dzieci oraz osób starszych. Zwraca się również uwagę na wypowiedzi o charakterze formalnym oraz nieformalnym (zob. np. zestawienie w tabeli wyrażeń z podziałem na formalne i nieformalne, tak jak w podręczniku Język polski dla stomatologów).

Brak znajomości zrytualizowanych zwrotów grzecznościowych charakterystycznych dla polskiej kultury (nawiązywanie kontaktu, użycie i wybór form adresatywnych: zwracanie się do przełożonych, podwładnych, współpracowników, pacjentów, zarówno do dzieci, jak i osób dorosłych, rejestr wypowiedzi formalnych i nieformalnych, używanie tzw. nośników „mądrości ludowej”, rozpatrywanie cierpienia i choroby w wymiarze religijnym, reakcja na tematy trudne, odpowiadająca polskim normom społecznym) może implikować frustrację obu stron. Szczególnie istotne są tutaj formy zwracania się do drugiej osoby stosowane w szpitalu, ponieważ okazują się specyficzne i często kontrastują z ogólnie przyjętymi zasadami grzeczności językowej. O istotnej roli tego

\footnotetext{
${ }^{11}$ WSJP kwalifikuje łokieć tenisisty jako wyrażenie medyczne, potoczne.
} 
zagadnienia może świadczyć tekst Andrzeja Markowskiego pt. Kultura języka w porozumiewaniu się lekarza z pacjentem (2014).

Z myślą o zdefiniowaniu kompetencji socjolingwistycznej autorki Co Panu dolega? (2015) zwróciły uwagę przede wszystkim na rolę języka potocznego ${ }^{12}$ oraz języka fachowego ${ }^{13} \mathrm{w}$ komunikacji medycznej. W podręczniku symbol gwiazdki - oznaczający wyrażenia „nacechowane stylistycznie bądź niepoprawne, ale często używane przez pacjentów lub personel medyczny" - został użyty 43 razy. Leksemy w ten sposób wyróżnione można zakwalifikować do następujących kręgów tematycznych ${ }^{14}$ :

1) Nazwy czynności fizjologicznych i ich rezultatów: siki; sikać (bezwiednie); siusiać; posikać się; kupka; kupa; robić kupę; sraczka; mieć wiatry

2) Nazwy (oraz opisy) nieprzyjemnych odczuć fizycznych oraz dolegliwości: dusi mnie; zatyka mnie; zasmarkany; wiatrówka; zimno (opryszczka); nadżerka; sepsa; zaczęty boleć mnie krzyże; o tutaj, zwłaszcza w nocy, a ściślej nad ranem

3) Nazwy czynności medycznych oraz opis leczenia: A siostra niech tymczasem cewnikuje pacjenta; Co pan teraz przetacza? Teraz idzie sól; Tak, trochę się poprawił, lejemy w niego płyny; Tak. Akurat zwolnit się drugi stól, miała tam iść niedrożność, która przyjęliśmy po południu, ale to będzie musiata poczekać; Przyszła już leukocytoza - 24 tys.; Tak, bo i tak miat iść brzuch; No to, Krzysiu, będziemy musieli tę rękę naprawić; Boję się, że zabieg nam może spaść, bo jest rozpisany na jutro; Został ustawiony na Phenytoine napady Jacksenowskie; Panie kolego, trzeba w końcu zmienić antybiotyk Jasiowi Adamskiemu, bo już pięć dni leczymy go cefalosporyna $i$ wyglada, że nie bardzo idzie nam to leczenie; Najpierw jednak muszę pania zbadać, potem zobaczymy, jak to się wszystko rozkręci; Ale jeżeli tylko się będzie dato, to sądzę, że spróbujemy urodzić dziecko dotem; cesarka; stać na hakach

4) Określenia stanu zdrowia pacjenta:

Tego, którego przywieźli we wstrzasie; Do tego brzuch jest brzydki; Ta noga może poczekać; No, to pewnie poszła śledziona; Był w leczeniu; Przed paroma dnami przyjęliśmy dość ciężkie dziecko; Leciał przez ręce; Na lekach miat ostatnio ciśnienie

5) Nazwy leków: odwadniacze

6) Miejsca związane ze szpitalem

Opatrunku proszę nie moczyć, a jutro zgłosi się pani z Krzysiem do chirurga w rejonie, do zmiany opatrunku; Zglosit się do rejonu

\footnotetext{
${ }^{12} \mathrm{Na}$ potrzeby tekstu przyjmuję, iż język $\leftrightarrow$ styl potoczny to: ,podstawowa odmiana funkcjonalna języka, znana wszystkim i przez wszystkich najczęściej używana. Stosowana jest głównie do porozumiewania się w codziennych sytuacjach życiowych, chociaż niektóre jej elementy mogą pojawiać się przede wszystkim w wypowiedziach ustnych (rozmowa przy stole, w sklepie, kłótnie, dowcipy itp.), ale możemy go także stosować w niektórych gatunkach pisanych (np. w prywatnych listach, e-mailach, krótkich wiadomościach tekstowych typu SMS, pamiętnikach, poradnikach)" (Zdunkiewicz-Jedynak 2006, 84).

${ }^{13}$ Język fachowy, w Małym słowniku terminów z zakresu socjolingwistyki i pragmatyki językowej nazywany również zawodowym, służy sprawnemu i ścisłemu przekazywaniu informacji (Skudrzykowa i Urban 2000, 80).

${ }^{14} \mathrm{~W}$ weryfikacji materiału pomogły następujące słowniki: SJP PWN, SJPD oraz WSJP.
} 
7) Varia:

Proszę mamy, założymy tu parę szwów i na ten czas mama sobie wyjdzie na korytarz. No to do roboty!, Panie kolego!

Zebrany materiał rozwiewa wątpliwości co do ich potocznego, fachowego lub żargonowego statusu ${ }^{15}$, co z perspektywy złożoności komunikacji medycznej staje się niezwykle istotne.

W dialogach funkcjonują obok siebie zwroty potoczne, terminologia fachowa, ale również leksyka charakterystyczna dla żargonu lekarskiego, o czym autorki we Wstępie nie wspominają. Wątpliwości budzi zasadność użycia określenia język fachowy, którego podstawowym celem jest sprawne i ścisłe przekazywanie informacji. Natomiast w zaprezentowanym zbiorze wyrażenia takie, jak choćby stać na hakach, odwadniacze, teraz idzie sól są przykładem żargonu lekarskiego. Osoby, które nie są związane ze środowiskiem medycznym, będą miały problem z ich zrozumieniem. $Z$ tego powodu za jedyną kwestią dyskusyjną w tym materiale uznać należałby oznaczenie tym samym symbolem graficznym leksyki nacechowanej stylistycznie (potocznie, fachowo, żargonowo) oraz słownictwa niepoprawnego (np. przymroczony, zagoraczkować16).

Dzięki analizie materiału udało się wyekscerpować dodatkowo 22 leksemy i wyrażenia, które nie zostały opatrzone kwalifikatorem graficznym przez autorki podręcznika, a WSJP i SJP PWN kwalifikują je jako potoczne. Są to określenie stanu zdrowia i natężenia bólu: strasznie; wykończony; jako tako; wrak ze mnie; marudny; kiepski; być na insulinie; leżé na zapalenie opon; dogadać się; język jak kołek; od wczoraj strasznie boli mnie serce; dostałem takiego strasznego ataku duszności, jak jeszcze nigdy dotąd; Pani doktor, zauważytem, że ostatnio strasznie dużo piję; Jestem wykończony!; Czuję się jako tako!; Wrak ze mnie; Już od potudnia jest taki nie bardzo przytomny, dużo śpi, nie można się z nim dogadać; Już w południe byt taki jakiś marudny; ale ona od dziecka jest na insulinie; rok temu leżat na zapalenie opon; kiepska morfologia; od kilku dni mam język jak kołek.

W dialogach można też potoczną frazeologię, np. zdrowy jak ryba; chodzić jak kaczka; wygladać jak łazarz; palce jak patyki; człowiek za kotnierz nie wylewa; odpukać $w$ niemalowane ${ }^{17}$.

Sytuacje komunikacyjne zaprezentowane w podręczniku są wiernym odzwierciedleniem tych rzeczywistych i prawdziwych. Niezaprzeczalnym atutem podręcznika jest

\footnotetext{
${ }^{15}$ Uważam, że wyrażenie zaczęly boleć mnie krzyże jest regionalne. WSJP rejestruje leksem krzyż w odniesieniu zarówno do całego kręgosłupa, jak i jego części. Nie wykorzystuje jednak przy tym kwalifikatora pot.

${ }^{16}$ Leksem przymroczony w języku polskim - a przynajmniej w odmianach polszczyzny znanych autorce - nie występuje. Można domniemywać, że jest to przykład potocznego neologizmu. Słownik języka polskiego PWN natomiast rejestruje leksem przytępiony w znaczeniu 'osłabiony, nadwerężony' oraz potocyzm przymulony, czyli 'zmęczony intensywną pracą umysłową'. Podobnie jak zagoraczkować. Analogiczna sytuacja dotyczy leksemu dopukać się. W podręczniku pojawia się on w zdaniu: No to nie chcę sobie dopukać, a autorki thumaczą go jako: doprawić się, dołożyć, pogorszyć. WSJP podaje użycie leksemu dopukać się w połączeniach z: do drzwi, w sprawie, do serca. Stownik języka polskiego pod red. W. Doroszewskiego - w znaczeniu 'pukać[,] aż będzie się usłyszanym'.

${ }^{17}$ Wynotowano również eufemizm chodzić na stronę i leksem przestarzały narywać.
} 
pokazanie lekarza w różnych sytuacjach zawodowych, co z kolei niejako wymusza sięgnięcie po inną odmianę języka. Dzięki temu osoba ucząca się poznaje reguły użycia języka w zależności od sytuacji i roli społecznej. Praca w szpitalu i kontakt z pacjentami w różnym wieku, pochodzącymi z różnych środowisk oraz posługującymi się różnymi odmianami i rejestrami polszczyzny, wręcz wymuszają na osobie uczącej się poznanie wariantów innych niż literacki czy standardowy. Zatem warianty polszczyzny pojawiające się w materiałach poddanych analizom okazują się jak najbardziej uzasadnione ${ }^{18}$.

\section{TECHNIKI ROZWIJANIA KOMPETENCJI SOCJOLINGWISTYCZNEJ W PODRĘCZNIKACH - IMPLIKACJE DLA GLOTTODYDAKTYKI}

Pojęcie technika rozumiem jako metodę w węższym przedziale działania, czyli planowe działanie prowadzące do uzyskania określonego celu, składające się z procesów myślowych oraz czynności praktycznych realizowanych w ustalonej kolejności (Szulc 1997, 130). Tak rozumiana technika pozwala uczącym się na wykształcenie zdolności przekładania polszczyzny potocznej na język specjalistyczny i odwrotnie, co w perspektywie przyszłego zawodu staje się niezwykle cenną umiejętnością (Masłowski 1977, 30).

Dialogi zaprezentowane w materiałach glottodydaktycznych okazują się reprezentatywne (z drobnymi wyjątkami) dla wzorców zachowania językowego znanego rodzimym użytkownikom polszczyzny.

Nie ulega wątpliwości, że we wszystkich podręcznikach największy nacisk kładzie się na nauczenie poprawnie brzmiących i skonstruowanych pytań, które mają służyć przeprowadzeniu merytorycznego i rzetelnego wywiadu. Dostrzegalne okazują się techniki uwzględniające rozróżnienie pytań kierowanych do dorosłego pacjenta i do dziecka. Do ciekawszych rozwiązań należą również transformacje poleceń z formalnych na nieformalne. $\mathrm{Z}$ perspektywy nauczania glottodydaktycznego osób wychowanych w innych kręgach kulturowych jest to niezwykle istotne. W podręczniku Co Panu dolega? (2015) stałym komponentem każdej jednostki lekcyjnej stały się ćwiczenia, w których osoba ucząca musi tę samą informację przekazać innym osobom (pacjentowi, pielęgniarce, przełożonemu, koledze-lekarzowi). W ten sposób czytelnik nabiera umiejętności językowego identyfikowania się z konkretną grupą społeczną i/lub zawodową.

Bardzo chętnie używano techniki odgrywania ról, która skutecznie kieruje uwagę uczących się na aspekty socjolingwistyczne. Tego typu rozwiązania można wykorzystywać w każdej grupie, bez względu na poziom znajomości zarówno języka ogólnego, jak i specjalistycznego (lub zawodowego). Wprowadzenie elementów dramowych pozwala przyswoić szybciej słownictwo specjalistyczne i strategie lingwistyczne,

\footnotetext{
${ }^{18}$ Agnieszka Kiełkiewicz-Janowiak i Magdalena Zabielska piszą: „W ochronie zdrowia dominuje obecnie pogląd, że w komunikacji z pacjentem należy unikać używania fachowej terminologii, ponieważ pacjent jej nie rozumie, a przynajmniej nie w ten sam sposób co lekarz. W celu zoptymalizowania komunikacji należy więc ocenić potrzeby i możliwości pacjenta (np. zakres jego obeznania z terminologią medyczną) i dostosować się do niego pod względem leksykalnym, na swój sposób «tłumacząc» specjalistyczny żargon na język, jeśli nie powszechnie" (Kiełkiewicz-Janowiak i Zabielska 2019, 46).
} 
pomaga w poprawie sprawności komunikacyjnych i wymowy, wpływa na utrwalenie relacji interpersonalnych: emocjonalnych, indywidualnych i grupowych (kompetencja socjokulturowa), a także - na improwizację oraz zapamiętywanie (kompetencja socjolingwistyczna i pragmatyczna) (Nowakowska 2017, 31).

Bardzo przydatne w doskonaleniu sprawności socjolingwistycznej mogą okazać się ćwiczenia na rozwijanie sprawności rozumienia ze słuchu, zwłaszcza te, w których uczący się mają za zadanie zidentyfikować typy wypowiedzi charakterystycznych dla różnych sytuacji, osób, grup społecznych. Niestety, takich ćwiczeń nie ma w podręcznikach.

Ćwiczenie często spotykane w podręcznikach, do którego polecenie brzmi: „Posłuchaj nagrania i zaznacz słowa, które są błędne”, można wykorzystać do rozwijania kompetencji socjolingwistycznej. Zamiast leksemow błędnych można wprowadzić słownictwo z innego rejestru, np. z języka potocznego czy żargonu, typowy regionalizm, idiom, wyrażenie frazeologiczne. Tego rodzaju ćwiczenia pomagałyby w nabywaniu umiejętności rozróżnienia różnych poszczególnych odmian języka.

Zadanie polegające na formułowaniu hipotez na temat znaczenia idiomów związanych z omawianym tematem jest ciekawą propozycją do wykorzystania w grupie osób o wyższym poziomie językowym.

Gwarancją sukcesu w komunikacji międzykulturowej (w tym - zwłaszcza na płaszczyźnie zawodowej) jest wyposażenie uczących się nie tylko w kulturę i wiedzę społeczną, lecz także w umiejętności socjolingwistyczne. Dlatego tak istotne stają się odpowiednio dobrane i urozmaicone rodzaju techniki oraz metody. Jak zaznacza Wojnicki:

W komunikacji obcojęzycznej do celów zawodowych - gdzie użycie języka obcego zwykle ma miejsce w sytuacjach, w których wiele może zależeć od wywieranego na rozmówcy wrażenia - gafy językowe omawianego typu mogą mieć poważne skutki. Wiele zależy od tolerancji, jaką dana społeczność przyznaje cudzoziemcom posługującym się jej językiem. Stopień owej tolerancji w wielu krajach bywa bardzo niski; dotyczy to jednak przede wszystkim nie wymowy lub poprawności gramatycznej, lecz właśnie sposobów użycia kodu językowego, związanych z wyrażaniem omawianych tu parametrów emocjonalnych i socjolingwistycznych, oraz niektórych funkcji komunikacyjnych te parametry odzwierciedlających (Wojnicki 1991, 78).

\section{PODSUMOWANIE}

Już w 1988 roku Robert Herbert pisał:

Socjolingwistyka ciągle pozostaje więc obiecującą dziedziną dla nauczycieli języków obcych w kwestii metod i materiałów. Jasne jest jednak, że nie ma w tej chwili jednoznacznych odpowiedzi na pytanie, w jaki konkretnie sposób wiedza socjolingwistyczna ma być włączona do materiałów gottodydaktycznych. Prowadzone obecnie badania nad zagadnieniami socjolingwistycznymi, zajmujące się nie tylko problemem zróżnicowania mowy w jej różnorakich aspektach, ale również kwestią celowości i sposobów posługiwania się językiem, odsłaniają kompleksową naturę interakcji czynników językowych, społecznych i kulturowych w kompetencji socjolingwistycznej (Herbert 1988, 118). 
W świetle przeprowadzonych badań można odnieść wrażenie, że przeszło trzy dekady później problem, na który zwrócił uwagę Herbert, pozostaje aktualny, zwłaszcza w odniesieniu do preparacji materiałów przeznaczonych do nauczania komunikacji medycznej.

Analiza takich materiałów glottodydaktycznych prowadzi do kilku spostrzeżeń.

Po pierwsze - autorzy starszych publikacji nie akcentują kompetencji socjolingwistycznej w opisie celów nauczania polskiego języka medycznego. Niemniej w materiałach podręcznikowych komponent socjolingwistyczny jest obecny w mniejszym lub większym stopniu. Wyjaśnieniem okazuje się powstawanie podręczników w różnych latach, zatem również w czasach, kiedy zmieniała się metodyka nauczania języka do celów ogólnych, ale również - do specjalistycznych. Ponadto wciąż nie opracowano programu nauczania języka polskiego do celów medycznych na gruncie nauczania języka polskiego jako obcego, który to program stanowiłby punkt odniesienia dla autorów materiałów glottodydaktycznych. Dodatkowym czynnikiem jest brak wypracowanej definicji kompetencji socjolingwistycznej w nauczaniu języka do celów specjalistycznych czy zawodowych.

Po drugie - w tych podręcznikach komunikacja medyczna została zredukowana do relacji lekarz - pacjent.

Po trzecie - z materiałów glottodydaktycznych wyłania się obraz pacjenta jako osoby, która jedynie udziela odpowiedzi na pytania lekarza. Utrwala to w przyszłych lekarzach przekonanie, że tylko po ich stronie leży zadawanie pytań. W materiałach brak dialogów, w których pacjent przejąłby inicjatywę w zadawaniu pytań lub poprosiłby o wyjaśnienie sensu wypowiedzi lekarza, np.: „Przepraszam, nie rozumiem; Co pan doktor ma na myśli?; Co to znaczy?".

Z kolei w podręcznikach na wyższych poziomach powiela się tendencję do zadawania przez lekarza kilku pytań jednocześnie. Tym samym zmniejszeniu ulega czas na odpowiedź pacjenta. Widać, że nowsze podręczniki - Co Panu dolega? (2015) i U lekarza (2019) - przynoszą inne niż dotychczas spojrzenie na rolę komponentu socjolingwistycznego w nauczaniu języków specjalistycznych. Ważne, aby materiały do nauczania języka polskiego w komunikacji medycznej nie powielały dotychczasowych praktyk, a autorzy bardziej zwracali uwagę na dyskutowane od lat problemy w komunikacji lekarz - pacjent.

Analizowany tutaj materiał dydaktyczny należy, mimo powyższych zastrzeżeń, docenić. Wszystkie wspomniane książki i materiały stanowią nieoceniony wkład w rozwój polskiej glottodydaktyki specjalistycznej, są nie tylko odzewem na zapotrzebowania rynkowe, lecz także próbą odpowiedzi na pytania, czym jest język medyczny oraz w jaki sposób i przy pomocy jakich materiałów go uczyć.

Problem badawczy zasygnalizowany w artykule nie wyczerpuje omawianego zagadnienia. Stanowi jedynie asumpt do kolejnych badań zorientowanych socjolingwistycznie. Nauczanie polskiego języka medycznego jest obecnie jednym z najbardziej eksploatowanych obszarów badawczych współczesnej glottodydaktyki polonistycznej. Dlatego też pilnego opracowania wymaga kompetencja socjolingwistyczna, jeden z elementów kompetencji komunikacyjnej. Dalsze badania skupią się na opracowaniu zagadnień socjolingwistycznych, socjokulturowych, realioznawczych w komunikacji medycznej, 
na wskazaniu stałych i podstawowych komponentów kompetencji socjolingwistycznej (funkcje mowy i akty mowy), na ustaleniu miejsca oraz roli kompetencji socjolingwistycznej w nauczaniu polszczyzny do celów medycznych - aby ostatecznie zaproponować definicję kompetencji socjolingwistycznej w nauczaniu języków specjalistycznych.

\section{BIBLIOGRAFIA}

Badziński, A. 2019. „Dyskurs w domenie języka specjalistycznego medycznego - uwagi dla tłumaczy i dydaktyków przekładu". Rocznik Przekładoznawczy. Studia nad teoria, praktyka i dydaktyka przekładu 14: 382-397.

Chłopicka, M., i D. Pukas-Palimąka. 1988. „Założenia lingwistyczne i metodyczne drugiej części podręcznika języka medycznego dla studentów polonijnych”. Przegląd Polonijny 2: 119-129.

Chłopicka-Wielgos, M., i D. Pukas-Palimąka. 1996. „Nauczanie języka specjalistycznego a nie tylko terminologii". Acta Uniniversitatis Lodziensis. Kształcenie Polonistyczne Cudzoziemców 7/8: 69-80.

Chojnacka-Kuraś, M. 2017. „Komunikacja medyczna jako obszar badań lingwistycznych”. Prace Filologiczne 71: 45-57.

Danecka-Chwals, A., D. Pukas-Palimąka, i M. Chłopicka. 1979. „Z zagadnień nauczania odmiany specjalistycznej języków obcych (na przykładzie nauczania języka medycznego studentów polonijnych)”. Przeglad Polonijny 5 (4): 73-82.

Danecka-Chwals, A., D. Pukas-Palimąka, i M. Chłopicka. 1981. „Założenia metodyczne i lingwistyczne podręcznika języka medycznego dla studentów polonijnych”. Przegląd Polonijny 7 (1): 57-67.

Dębski, R. 1996. Komputer w nauczaniu języka polskiego. Przetwarzanie języka w programach dydaktycznych. Kraków: Wydawnictwo Uniwersytetu Jagiellońskiego.

Doroszewski, J. 2007. „Komunikacja pacjenta z lekarzem - literatura, stanowiska, problemy”. W Językowe, psychologiczne i etyczne aspekty komunikacji lekarza z pacjentem, oprac. M. Kącka. Warszawa: Rada Języka Polskiego przy Prezydium PAN, 41-62.

Dudzik, A. 2014. „Co to znaczy nauczać języka medycznego”. Języki Obce w Szkole 1: 73-76.

ESOKJ. 2003. Europejski system opisu kształcenia językowego: uczenie się, nauczanie, ocenianie. Warszawa: CODN.

Fuhrmann, K. 2012. „Na potrzeby rynku pracy: kształcenie tłumaczy i kształcenie językowe pracowników”. W Kompetencje językowe podstawa sukcesu zawodowego i społecznego w Europie, red. H. Komorowska, i J. Zając. Warszawa: Fundacja Rozwoju Systemu Edukacji, 181-184.

Gajewska, E., i M. Sowa. 2014. LSP, FOS, Fachsprache ... Dydaktyka języków specjalistycznych. Lublin: Werset.

Gębal, P.E. 2016. „Od dydaktyki tekstów specjalistycznych do dydaktyzacji potrzeb i działań komunikacyjnych. Kierunki i koncepcje glottodydaktyki specjalistycznej”. Acta Universitatis Lodziensis. Kształcenie Polonistyczne Cudzoziemców 23: 20-33.

Herbert, R.K. 1988. „Wykorzystanie socjolingwistyki w sali lekcyjnej: perspektywy i przestrogi”. W Z teorii i praktyki tworzenia materiatów glottodydaktycznych. Materiał X Sympozjum Instytutu Lingwistyki Stosowanej Uniwersytetu Warszawskiego, red. F. Grucza. Warszawa: Wydawnictwo Uniwersytetu Warszawskiego, 105-120.

Hofstede, G.H. 1997. Cultures and Organizations: Software of the Mind. New York: McGraw Hill. 
Jarosz, M. 2013. „Przekazywanie niepomyślnych informacji w praktyce klinicznej”. Via Medica 9 (6): 225-229. Kiełkiewicz-Janowiak, A., i M. Zabielska. 2019. „Komunikacja lekarz - pacjent: krytyczna analiza dydaktycznych materiałów instruktażowych". W Językowe, prawne i dydaktyczne aspekty porozumiewania się z pacjentem, red. M. Kulus, A. Doroszewska, i M. Chojnacka-Kuraś. Warszawa: Polska Akademia Nauk, 40-56.

Konopka, M.N. 2016. Komunikacja lekarz - pacjent. Teoria i praktyka. Kraków: Instytut Dziennikarstwa i Komunikacji Społecznej.

Ligara, B., i W. Szupelak. 2012. Lingwistyka i glottodydaktyka języków specjalistycznych na przykładzie języka biznesu. Podejście porównawcze. Kraków: Księgarnia Akademicka.

Ławnicka-Brońska, M., i K. Kubicka. 2016. „Język polski medyczny w wybranych materiałach dydaktycznych ostatniego ćwierćwiecza”. Acta Uniniversitatis Lodziensis. Ksztatcenie Polonistyczne Cudzoziemców 23: $215-234$.

Ławicka-Borońska, M., W. Rudnik, i J. Wiśniewska. 2011, „Kurs języka polskiego jako obcego dla studentów medycyny". W Nowe perspektywy w nauczaniu języka polskiego jako obcego II, red. K. Pluskota, i K. Taczyńska. Toruń: Wydawnictwo Naukowe Uniwersytetu Mikołaja Kopernika, 321-332.

Magajewska, M. 2016. „Specjalistyczny język medyczny a multimedialny kurs języka zawodowego dla pielęgniarek". Acta Uniniversitatis Lodziensis. Kształcenie Polonistyczne Cudzoziemców 23: 199-213.

Markowski, A. 2006. „Kultura języka w porozumieniu się lekarza z pacjentem”. W Porozumienie się z pacjentem, red. J. Doroszewski, M. Kulus, i A. Markowski. Warszawa: Wolters Kluwer Polska.

Marshal, R.S. 1986. Doctors and Sense: A Sociolinguistic Analysis of Doctor-Patient Communication. Berkeley: UCSF Joint Medical Program.

Masłowski, J. 1977. Polskie stownictwo lekarskie. Wrocław: Wydawnictwo Polskiej Akademii Nauk.

Menz, F. 2010. „Doctor-Patient Communication”. W The SAGE Handbook of Sociolinguistics. London: SAGE Publications Ltd., 330-344.

Miodunka, W.T. 2016. Glottodydaktyka polonistyczna. Pochodzenie-stan obecny-perspektywy. Kraków: Księgarnia Akademicka.

Müldner-Nieckowski, P. 2014. „Uwagi o odmianach języka lekarskiego”. W Znaczenie, tekst, kultura. Prace ofiarowane Profesor Eżbiecie Janus, red. A. Kozłowska, i A. Świątek. Warszawa: Wydawnictwo Uniwersytetu Kardynała Stefana Wyszyńskiego, 399-412.

Nowakowska, P. 2017. „Kształcenie kompetencji socjokulturowej poprzez użycie technik dramowych na zajęciach języka hiszpańskiego". Języki Obce w Szkole 4: 31-36.

Oczko, P. 2020. „Techniki rozwijania sprawności słuchania i mówienia w podręcznikach do nauczania polskiego języka medycznego". Acta Uniniversitatis Lodziensis. Ksztatcenie Polonistyczne Cudzoziemców 27: 435-450.

Oczko, P. 2021. „Techniki rozwijania sprawności czytania oraz pisania w materiałach do nauczania polskiego języka medycyny (medycznego)" [w druku].

Simmons, M. 1998. A Sociolinguistic Analysis of Doctor-Patient Communication. [b.m.w.].

Skudrzykowa, A., i K. Urban. 2000. Mały słownik terminów z zakresu socjolingwistyki i pragmatyki językowej. Kraków: Towarzystwo Miłośników Języka Polskiego.

Smith, P.B., i F. Trompenaars. 1996. „National Culture and the Values of Organizational Employees: A Dimensional Analysis Across 43 Nations". Journal of Cross-Cultural Psychology 27 (2): 231-261. Sobczak, K. 2014. „Przekazywanie informacji o niekorzystnej diagnozie i rokowaniu”. Via Medica 8 (6): 320-328. 
Sobczak, K., i K. Leoniuk. 2021. „Doctor’ attitudes in situation of delivering bad news: patient’s experience and expectations". Archives of Medical Science 1: 1-9.

Swoboda-Rydz, U. 2018. „Czy możliwe jest zanurzenie w języku specjalistycznym”. W Wyzwania glottodydaktyki polonistycznej. „Życie zaczyna się po sześćdziesiątce”, red. P. Potasińska, i M. Stasieczek-Górna. Warszawa: Polonicum, 203-213.

Szuc, A. 1997. Stownik dydaktyki języków obcych. Warszawa: Wydawnictwo Naukowe PWN.

Taczyńska, K. 2011. „Językowe dolegliwości lekarzy obcokrajowców”. W Nowe perspektywy w nauczaniu języka polskiego jako obcego II, red. K. Pluskota, i K. Taczyńska. Toruń: Wydawnictwo Naukowe Uniwersytetu Mikołaja Kopernika, 293-302.

Wojnicki, S. 1991. Nauczanie języków obcych do celów zawodowych. Warszawa: Wiedza Powszechna.

Zarzycka, G. 2008. „Kultura, lingwakultura, socjokultura w nauczaniu języka polskiego jako obcego”. W Rozwijanie i testowanie biegłości w języku polskim jako obcym, red. A. Lipińska, i E. Seretny. Kraków: Universitas, 143-160.

Zdunkiewicz-Jedynak, D. 2006. „ABC stylistyki”. W Polszczyzna na co dzień, red. M. Bańko. Warszawa: Wydawnictwo Naukowe PWN, 33-96.

Zhura, V., i J. Rudova. 2019. „Developing communicative competence in students of Higher Medical School". Medical University 2 (1): 1-4.

\section{WYKAZ ANALIZOWANYCH MATERIALÓW}

Bilicka, B. 2018. Witaj w Polsce! Podręcznik do nauki języka polskiego dla studentów medycyny. Szczecin: Wydawnictwo Pomorskiego Uniwersytetu Medycznego.

Bilicka, B., i A. Leśniak. 2013. Język polski dla cudzoziemców. Dialogi i ćwiczenia dla studentów stomatologii. Szczecin: Wydawnictwo Pomorskiego Uniwersytetu Medycznego.

Chłopicka-Wielgos, M., D. Pukas-Palimąka, i K. Turek-Fornelska. 2015. Co Panu dolega? Podręcznik z plyta CD do nauczania cudzoziemców języka polskiego na studiach medycznych. Poziom B2/Cl. Kraków: Fundacja Wspierania Kultury i Języka Polskiego im. Mikołaja Reja.

Janeczko, D. i in. 2014. Materiały do nauczania języka polskiego w szkole medycznej dla obcokrajowców. Poziom podstawowy. Kraków: Wydawnictwo Attyka.

Janowska, M., i Ś. Sikorska. 2019. Proszę oddychać. Materiały do nauczania medycznego języka polskiego. Cz. 1. Warszawa: [Oficyna Wydawnicza Akademii Medycznej].

Janowska, M., i Ś. Sikorska. 2020. Proszę oddychać. Materiały do nauczania medycznego języka polskiego. Cz. 3. Warszawa: [Oficyna Wydawnicza Akademii Medycznej].

Jurek, T. 2007. Proszę mi powiedzieć, co się stało? Podręcznik języka polskiego dla studentów medycyny. Poznań: Wydawnictwo Naukowe Uniwersytetu Medycznego im. Karola Marcinkowskiego.

Rogala, D. i in. 2019. U lekarza. Stucham i rozumiem! Materiały do nauczania języka polskiego medycznego. Poziom A2-B2. Kraków: Wydawnictwo Avalon.

Swoboda-Rydz, U. 2016. Język polski dla stomatologów. Warszawa: Oficyna Wydawnicza Akademii Medycznej. 


\title{
WYKAZ ŹRÓDEŁ INTERNETOWYCH
}

https://escholarship.org/uc/item/53v3d003 (22 marca 2021).

https://files.eric.ed.gov/fulltext/ED424785.pdf (21 marca 2021).

https://linguistik.univie.ac.at/fileadmin/user_upload/i_sprachwissenschaft/CV/Menz/5434-Wodak-Chap-

23-doctor-patient-comm.pdf (10 marca 2021).

https://nil.org.pl/dla-lekarzy/mlodzi-lekarze/4282-egzaminy-z-jezyka-polskiego (4 lutego 2021).

https://sciendo.com/doi/10.2478/medu-2019-0001 (17 marca 2021).

https://sjp.pwn.pl/ (19 marca 2021).

https://wsjp.pl/ (19 marca 2021).

https://www.health.gov.il/publicationsfiles/healthataglance2015.pdf (19 marca 2021).

\section{Sociolinguistic Dimension of Medical Communication in Teaching Polish as a Foreign Language}

Keywords: sociolinguistic aspect, sociolinguistic competence, techniques for developing sociolinguistic skills, specialist language, medical Polish, medical communication, socio-culture, lingua-culture.

\begin{abstract}
The article is a contribution to the discussion on the issue of sociolinguistic competence in teaching Polish as a foreign language for specialist purposes. The text has a research character and constitutes one of the concepts of achieving a definition of sociolinguistic competence. An in-depth analysis of the content (the existing state) of the textbooks on teaching Polish medical language is placed in the linguistic and socio-cultural stream of linguistic research, while the functional context of the tested materials places the presented considerations within the methodological specificity of glottodidactics. In the cognitive dimension, the aim is to broaden the knowledge of the development of sociolinguistic competence in teaching specialist languages on the example of medical language. The first part of the article presents theoretical approaches to sociolinguistic competence in language teaching for general and professional purposes. The second part presents the authors' concepts concerning the presence of a sociolinguistic component in the materials for teaching Polish medical language. The third part confronts these concepts with the actual state and content of the textbooks. The analysis of the glottodidactic materials made it possible to indicate the most frequently used techniques for teaching sociolinguistic skills, to which the fourth part of the article is devoted. The results of the analysis have shown that in the vast majority of textbooks the authors do not explicitly emphasise sociolinguistic competence in the description of the objectives of teaching Polish medical language, although in the textbook materials themselves the sociolinguistic component is present to a greater or lesser extent. The weak points of the analysed materials include the presentation of only doctor-patient dialogue situations, omitting at the same time doctor-patient family, doctor-doctor, doctor-medical staff communication. As a result, the sociolinguistic component is not fully presented to the learner.
\end{abstract}

